\title{
Learning Leadership:
}

\author{
Improving Academic Quality in Improving Teacher Performance
}

\author{
Indah Anggraeni*, Taufani Chusnul Kurniatun \\ Educational Administration Department, School of Postgraduate Studies \\ Universitas Pendidikan Indonesia \\ Bandung, Indonesia \\ *Indaha@upi.edu,taufani@upi.edu
}

\begin{abstract}
This study aims to determine the activities of the principal in influencing people who carry out busy academic activities at school, related to learning as an effort to improve academic quality in improving teacher performance. This study uses a survey method through a quantitative approach. Respondents in this study were educators (teachers, and educational staff). The findings and test of simple and multiple regression correlation analysis are expected to prove the hypothesis of this study. Partial research results regarding learning leadership in simple terms, learning leadership in improving academic quality to improve teacher performance require a school supervisor as part of the management system to provide clear mapping of tasks for teaching staff and to control the implementation of learning by teachers. Learning leadership requires professional assistance in improving teacher performance to improve academic quality in schools.
\end{abstract}

Keywords-academic quality, learning leadership, teacher performance

\section{INTRODUCTION}

Developments in the economic sector are influenced by improvements in the quality of education for the national development process. Education is an investment in the development of human resources, a sustainable action in paving attention to the development of human resources into a good policy to improve the quality of education. One of the important issues in the implementation of education in Indonesia is finding ways to improve the quality of education in the midst of the changing times that are moving very fast today. The components that are crucial in the learning process of education in schools include the teacher. Once the importance of the role and responsibilities of teachers, Act No. 14/2005 on Teachers and Lecturers mentions teachers as learning agents who must be facilitators, motivators, stimulators, learning engineers, and inspirational learners for students. In addition, teachers also have the main task of educating, teaching, guiding, directing, training, assessing, and evaluating students in early childhood education through formal education, basic education, and secondary education. Thus, central to the success of the education continuity process is the quality of teacher performance. Teachers have an important role in educating the lives of the nation's children, especially in shaping the national personality based on positive values that are desired and developing the potential of each student. In addition, the task of teachers in the school is to provide services to students so that they become students or students who are in line with the goals of the school.

In reality, expectations are not yet in accordance with reality. Based on the research results of the Research and Development Agency for the National Education Service in 2006 , it was stated that the low quality of our education was caused by many factors, and one of the factors that made a big contribution was the teacher factor. Research conducted by UNESCO through the 2016 General Education Monitoring (GEM) Report places education in Indonesia in 10th position out of 14 developing countries. Assessment of teacher quality places Indonesia in 14th place out of 14 developing countries or in the lowest position. This has an impact on the quality of education which becomes low. There needs to be an innovation that provides solutions to problems with the quality of teacher performance.

The condition of the quality of education in Indonesia is currently very bad at various levels, both at the primary, secondary and tertiary levels, as shown by various studies. At this time, the challenge of the Indonesian nation to be able to improve the quality of education is the quality of teachers in schools. How the four teacher competencies covering professional, pedagogic, personality and social competences should be improved. Two absolute competence to do selfdevelopment professional competence and pedagogic. Professional competence is needed to improve teachers' abilities in learning content and pedagogical competencies are needed to improve teacher skills when teaching, planning, providing assessments, designing learning methods, class management and others. To be able to improve the quality of teachers in increasing their competence, apart from within the teacher itself the principal also has a very important role.

Priansa argues that the principal is defined as a functional teacher who is assigned the task of leading a school where the teaching and learning process is held, or a place where interactions occur between teachers who provide lessons and students who receive lessons [1]. One of the duties of the 
principal is instructional leadership. The definition of learning leadership according to Eggen and Kauchak is an action taken (the principal) to develop a productive and satisfying work environment for the teacher, which in turn can create better student learning conditions [2]. Learning leadership according to Bush and Glover is leadership that emphasizes components that are closely related to learning, including curriculum, teaching and learning processes, assessment, teacher development, excellent service in learning, and building learning communities in schools [3].

The main objective of learning leadership is to provide excellent service to all students so that they are able to develop their potential, talents, interests and needs. In addition, to facilitate learning so that students' learning achievement increases, learning satisfaction is higher, learning motivation is higher, curiosity is realized, creativity is fulfilled, innovation is realized, an entrepreneurial spirit is formed, and awareness for lifelong learning because science and technology and art develop rapidly and grow well.

From the description above, how can the principal as the leader of learning to improve academic quality in improving teacher performance at SMP Al-Azhar Syifa Budi Parahyangan.

\section{RESEARCH METHODS}

This research uses a quantitative approach with a descriptive survey method. Quantitative descriptive survey method is a research method that takes a sample from a population and uses a questionnaire as a data collection tool. Descriptive research is a research design that is structured in order to provide a systematic description of scientific information derived from the subject or object of research [4]. The variables in this study were principal learning leadership (X1), academic quality improvement (X2) and teacher performance $(\mathrm{Y})$. The quality of teacher performance in this study is seen from the dimensions of reliability, responsiveness, assurance, empathy, physical evidence. The learning leadership is seen from continuous improvement, learning culture, assessment of learning outcomes, teacher professional development, school management and differences. While the improvement of academic quality is seen from the dimensions of performance, time, reliability, durable data, beautiful, human relations, easy to use, special forms, certain standards, consistency, uniformity, serviceability, accuracy. Research The population used as the object of this study were all teachers of SMP Al-Azhar Syifa Budi Parahyangan.

\section{RESEARCH RESULTS AND DISCUSSION}

Leadership Learning in improving the academic quality to improve teacher performance shows that there is a positive and significant influence between learning leadership principals to teachers' teaching performance quality. The magnitude of the influence of the principal's learning leadership on the quality of teacher teaching performance is $17.1 \%$, the remaining $82.9 \%$ is influenced by other variables. Furthermore, from the calculation of the regression analysis shows that for each additional one point, the teacher's teaching performance will increase by 0.525 points. This means that the better the principal's learning leadership, the better the quality of the teacher's teaching performance. Thus the principal's learning leadership is one of the factors that influence teacher teaching performance. Principal learning leadership affects the quality of teacher teaching performance, due to the principal's activities that really focus on improving the process and student learning outcomes through the teacher. This means that learning leadership empowers all teachers' abilities in teaching so that teacher teaching performance increases. Quality teacher teaching performance will in turn improve the process and student learning outcomes because student learning outcomes are not directly from the principal's learning leadership, but through the teaching process carried out by the teacher. The results are consistent with research findings Cicih and Endang is a principal in practice leadership should improve the quality and learning outcomes components consist of curriculum, learning activities, evaluation / assessment, empowerment and professional development teachers, improving learning services, and building learning communities [1]. Thus, there must be a new paradigm of primary school principal leadership practices that must focus more on improving the quality and learning outcomes. The concept of learning leadership puts the teacher as the main variable in the event of a learner a $n$. The teacher is the most important factor in the occurrence of the learning process through teacher teaching activities. In learning leadership, the main factor that must be influenced is the teacher so that they prioritize improving the quality of teaching so that there is an increase in the learning process. Generate significantly positive thing where influence on teachers' performance is $38.4 \%$, while the remaining $61.6 \%$ is influenced by other variables. Furthermore, the calculation of the regression analysis shows that each addition of one point will increase by 0.610 points, so that there needs to be supervision of the teacher so that the teaching performance of the teacher will increase. Thus, school principals need to carry out school supervision which is one of the factors that has an influence on teacher teaching performance. Supervision in schools is needed because with supervision people will avoid working arbitrarily. According to M Rival stated that with the supervision of the officers or executive will be more cautious in carrying out his job and pay more attention to the provisions that have been outlined [3]. They will avoid mistakes.

Teachers are professionals who are tasked with planning, implementing and assessing academic activities as well as in teaching activities. (National Education System Law No. 20 of 2003, Article 39). In the school environment, compliance with applicable regulations is highly demanded, because administratively the teacher is an education employee who must obey the organization and the boss who leads it, as applicable in the employment regulations. In carrying out their duties, teachers are bound by staffing norms and rules, which causes them to work based on the rules. The duties of teachers as teaching staff include (Kepmendiknas RI No. 056 / U / 2001): 1) providing educational technical services for the 
teaching and learning process and its assessment, both theory and practice for all subjects; 2) support and extracurricular services, such as sports, arts, UKS, youth red cross, scouts, study tours; 3) maintenance of learning facilities and infrastructure, laboratories, libraries, and skills practice equipment ; 4) supervision of the safety of students, use of learning facilities and extracurricular activities; 5) participation in various competition activities and community activities that include students. As a teacher education employee must obey bureaucratic provisions, the teacher cannot escape in implementing it. The principal as his superior is obliged to control and supervise all teacher duties that must be done because it is part of his responsibility as an employee. The principal evaluates all the tasks carried out by the teacher. As a member of the bureaucracy, teachers are required to be loyal and obedient to the state in carrying out their daily duties, discipline and obedience as employees in carrying out their work. Compliance with performing duties according to the rules is a norm that must be obeyed. That is what causes him to receive supervision, inspection, and supervision from the principal as superior and teaching leader in his school. Because if it is not monitored, all norms and rules may be violated and ignored. Principals in improving academic quality to improve teacher performance as learning leaders can provide professional assistance. Significantly, the difficulties faced by the teacher when teaching were solved in their own way. Solving problems in this way is an individual action that will not result in a holistic institutional change. So that the principal needs to provide assistance for professionalism as a teacher. Professional assistance to develop teachers' abilities at work is an indispensable condition if teachers want to develop in a better direction according to the desired institutional changes. The basic abilities they already have can be further developed in the field according to the job needs in accordance with the task at hand. Supervision of professional assistance is empowerment in the form of continuous guidance given to teachers in accordance with the development of their demanding work. Assistance in the form of technical improvement in the methodological learning of individual difficulty solving, enrichment or curriculum development, mastery of learning materials, making worksheets using learning resources and selecting textbooks.

\section{CONCLUSION}

Academic quality at SMP Al-Azhar Syifa Budi Parahyangan from the results of research and literacy studies shows that the principal as the leader of learning needs to take actions that pay attention to teacher performance in improving teacher professionalism in carrying out their duties. Problems that occur when problems are experienced by teachers in carrying out their duties require significant action by the principal. Among them are conducting school supervision and providing professional assistance to teachers so that academic quality can increase.

\section{REFERENCES}

[1] E. Cicih, "Kepemimpinan Instruksional Kepala Sekolah, Komitmen Guru dan Mutu Kinerja Mengajar Guru," Jurnal Administrasi Pendidikan, vol. 22, no. 1, 2015.

[2] Pemeri ntah Indonesia. Law Number 20 of 2003 concerning the National Education System

[3] M. Rivai, Administrasi Pendidikan Dan Supervisi Pendidikan. Bandung: Jenmars, 1982.

[4] S. Sandu, Basic Research Methodology. Yogyakarta: Media Publishing Literacy, 2015. 